\title{
The Contemporary Conception of Human Rights: Between Concepts, Foundations and Distinctions
}

\begin{abstract}
Paiva FSC*
Graduation in Law (FACEP) and Accounting Sciences (UERN). Specialist in Public Accounting (FINOM) and Tax Law (UCAM). Master in Environment, Technology and Society (UFERSA). Pau dos Ferros-RN/ Brazil
\end{abstract}

*Corresponding author: Francisco Cleiton Silva Paiva, Graduation in Law (FACEP) and Accounting Sciences (UERN). Specialist in Public Accounting (FINOM) and Tax Law (UCAM). Master in Environment, Technology and Society (UFERSA).Pau dos Ferros-RN/ Brazil, Email: cleiton_paiva@hotmail.com

\section{Review Article}

Received Date: March 29, 2021

Published Date: April 20, 2021

DOI: $10.23880 /$ abca-16000178
Volume 4 Issue 2

\section{Abstract}

This work aims to present and discuss the contemporary conception of human rights theory.Based on the defense of the dignity of the human person, human rights are the result of conquests throughout history, having taken effect in the international order since the end of the Second World War, when the United Nations (UN) promulgated the Universal Declaration of Human Rights. Human Rights, in 1948, when this document became the normative framework for humanitarian protection worldwide. The aforementioned Declaration provides for a set of rights belonging to every human person, regardless of nationality, race, sex, religion or any other characteristic. Among these rights are the right to life, freedom, food, work, among others, which underpin a dignified existence. In contemporary theory, although there are various ways of designating human rights, such as "human rights","individual rights","fundamental rights", "natural rights", among others, these expressions have the same meaning. However, the majority doctrine essentially distinguishes two terminologies as to its scope: "human rights", which are used to define the rights established by international law; and "fundamental rights", which corresponds to those referring to the rights recognized and affirmed by the States, as occurs in Brazil, in the text of the Federal Constitution of 1988. In methodological terms, this article deals with a review study, categorized as qualitative (as to nature), descriptive (as to objective) and bibliographic (as to object) research.

Keywords: Human rights; Contemporary Theory; Fundamental rights; Dignity

\section{Introduction}

The United Nations (UN) defines human rights as a set of rights inherent to all human beings, regardless of race, sex, nationality, ethnicity, language, religion or any other condition (UN, 2020) [1]. The right to life, freedom, freedom of opinion and expression, education, work, among others, are part of the list of rights protected and granted to all humanity, without any distinction.

Faced with the atrocities that occurred in the Second World War, after its end, the countries decided to unite to prevent other events of this nature from happening again, thus seeking to provide greater protection for humanity. In this environment, the UN enacted, in 1948, the Universal Declaration of Human Rights, an international normative protection document to guide States in protecting the rights of the human person worldwide. The Declaration arose from the need for an international protective architecture and the emergence of international human rights law [2].

Alexandre De M, et al. [3] points out that the Universal Declaration of Human Rights represented the most important achievement of fundamental human rights at the international level in the entire 20th century. In the Declaration, which would cover all nations, the supreme 
values of equality, freedom and fraternity were recognized, the motto of the French Revolution of 1789.

At that time, the greatest concern was to grant and guarantee the minimum and fundamental rights for all people, guaranteeing not only their right to life, but also to a full existence, being really a subject of rights. After the Universal Declaration of 1948, the meaning of "human rights" started to be redesigned, as stated by Sven P, et al. [4]: "Considering the historicity of these rights, it can be said that the definition of human rights points to a plurality of meanings. In view of this plurality, the so-called contemporary conception of human rights stands out" Sven P, et al. [4]:

The meaning of the expression "human rights" has its genesis in the idea of recognition and protection. First, it is necessary to understand that human rights are the result of achievements throughout human history. For didactic purposes, however, Rafael B, et al. [5] states that the expression human rights has been used to identify the rights inherent to the human person, in the international order. However, it is common to observe a variety of definitions for human rights, making it difficult at times to have a concrete understanding of the subject.

This work aims to present and discuss the contemporary conception of human rights theory. To do so, we approach the main concepts and definitions, foundations, characteristics and distinctions about these rights. Given the complexity of defining what these rights are, we will seek support from some human rights thinkers, theorists and jurists who have formulated ideas on the subject, both in the past and today. For this reason, the present study corresponds to a review study based on the study of leading authors in the area of human rights, such as Sven P, et al. [4]; De Carvalho RA, et al. [6]; Melina Girardi F, et al. [2]; Gomes CJJ, et al. [7]; Norberto $\mathrm{B}$, et al. [8], among others.

As for the methodological aspects, the present research is categorized, regarding the nature of the research, as qualitative research; regarding the research objectives, defined as descriptive; and, as for the object, considered a bibliographic search.

\section{Human Rights: Concepts and Definitions}

Rights they arise as a result of social evolution and this does not happen overnight. So that today we can enjoy a legal system in the order of a Democratic State of Law, much has been done, gradually, slowly and with several comings and goings. The lawyer Norberto B, et al. [8] says that "rights are not born all at once". A succinct description, however, needs to be understood, that the law is the result of a historical evolution and that has man as the protagonist. In another famous and notable position, the thinker explains thatthe most fundamental human rights are historical rights, "born in certain circumstances, characterized by struggles in defense of new freedoms against old powers, and born gradually, not all at once and not once and for all" [8].

Norberto B, etal. [8] in his reflection on how rights emerge, speaks to respeito of the dimensions of the rights and brings very clearly the understanding that these dimensions arise with a process of evolution. For example, third-dimensional rights, such as those relating to the environment, could never have been conceived when second-dimensional rights were proposed, just as they could not have been imagined at the time of the conception of first-dimensional rights. This is because they have emerged over time, over the course of history. Then, as new needs emerge, these ideas of protection from the law emerge.

At the international level, the normative human rights system gained strength after the Second World War. We can say that the internationalization of human rights arose from a post-war movement, in the face of the horrors committed by the Nazi state in Germany, which stood out for the contempt and discard of human beings. Sven P, et al. [4] draws an overview of how this reframing took place:

It is in this scenario that the effort to reconstruct human rights is designed, as a paradigm and ethical framework to guide the contemporary international order. By crystallizing the logic of barbarism, destruction and disposability of the human person, World War II symbolized the rupture with respect to human rights, meaning the post-war the hope of reconstructing those same rights. The need to protect human beings from other damaging events was its source in the contemporary era, not of emergence, but of a resurgence. This has a raison d'être and very simple to understand, as explained by Sven P, et al. [4]:

At the moment when human beings become superfluous and disposable, at the moment when the logic of destruction prevails, when the value of the human person is cruelly abolished, the reconstruction of human rights becomes necessary, as an ethical paradigm capable of restoring the logic of the reasonable.

It was from this rupture that the need to reconstruct human rights emerged. At that time, the greatest concern was to grant and guarantee the minimum and fundamental rights for all people, guaranteeing not only their right to life, but also to a full existence, being really a subject of rights. After the Universal Declaration of 1948, the meaning of "human rights" started to be redesigned, as stated by Sven $\mathrm{P}$, et al. [4]: "Considering the historicity of these rights, it can be said that the definition of human rights points to a plurality of meanings. In view of this plurality, the so-called 
contemporary conception of human rights stands out".

The idea of "human rights" has in its genesis a sense of recognition and protection. "Human rights were not given, or revealed, but conquered, and often at the cost of sacrificing lives," recalls. The author states that, for didactic purposes, the term human rights has been used to identify the rights inherent to the human person, in the international order.

In view of how it came about, it is also necessary to explain the content of these rights, as well as their definition. Given the complexity of defining what these rights are, we will seek support from some human rights thinkers, theorists and jurists who have formulated ideas on the subject, both in the past and today. However, De Souza NG, et al. [9], makes a reservation regarding the definition of human rights, which we would like to quote, before using the various concepts relevant to the matter:

The key point is to decipher the content and scope of this famous and widespread expression: human rights. Naturally, in terms of absolute simplicity, it is the rights of the human being. However, having said that, the definition is absent, as well as its scope. It must be considered that human rights, in the first place, are exclusive to human beings, moving away from things and animals. Second, they must be basic rights, without which the human being perishes. One begins to find a deeper meaning, establishing some boundaries. The first generation or dimension rights come from jusnaturalism, to the point of more conservative positions defending that only these are human rights. They are the only universal and valid rights.

However, the doctrine is lavish in presenting us with concepts, the most varied and precise on the subject of human rights, saying exactly what we intend to expose. The United Nations (UN) itself defines human rights as follows: "Human rights are inherent rights to all human beings, regardless of race, sex, nationality, ethnicity, language, religion or any other condition"(UN, 2020 [1]). According to the UN, these rights include the right to life, freedom, freedom of opinion and expression, education, work, among others, which must be conferred on all human beings, without any discrimination, as we can see Next:

The human rights conceptrecognizes that each human being can enjoy his human rights without distinction of race, color, sex, language, religion, political or other opinion, social or national origin or condition of birth or wealth. Human rights are legally guaranteed by human rights law, protecting individuals and groups against actions that interfere with fundamental freedoms and human dignity (UN, 2020) [1].

As defined by Walter $\mathrm{K}$, et al. [10], "it is the sum of civil, political, economic, social, cultural and collective rights stipulated by international and regional instruments and international custom". It is a comprehensive and formal definition, considering the fact that the defense of human rights at the international level operates based on legally binding norms and based on positive law, as explained by Sven P, et al. [4]. The author considers that, among the definitions of "human rights", this is the most complete, because:

- Reports to the main sources of the IACHR, that is, international treaties and international custom. It is safe to say that knowledge of these concepts is indispensable for the understanding and practical application of the IHRD;

- It concerns the difference between individual and collective HD. This allows us to analyze the issue of DHI ownership;

- Makes reference (indirect or even involuntary) to the socalled "generations" of DHI;

- Implicitly recognizes the indivisibility, interrelationship and interdependence of human rights;

- Recalls the division of the international human rights protection system into the universal system and regional systems [4].

Sven $\mathrm{P}$, et al. [4] notes that understanding the meaning of human rights is important and also a basic assumption for the identification of individual guarantees contained in human rights documents, as well as the obligations and protections arising from them.

We know that to be a subject of human rights there is only one condition: human being. Along these lines, Ricardo C, et al. [11], teaches that human rights can also be defined as a "set of rights that are recognized as belonging to human beings by their very nature". Filho C, et al. [12], in turn, understands human rights "as the rights considered basic for any human being, regardless of specific personal conditions. These are rights that make up an intangible nucleus of the rights of human beings subject to a certain legal order".

Based on the theory of Thomas Paine (British thinker and jurist, author of "The Rights of Man"), there is a doctrinal current that, according to André Ramos T, et al. [13], presents a definition of jusnaturalist bias, according to which human rights are: "the conjunction of natural rights, which correspond to Man by the mere fact of existing, and civil rights, that is to say, that set of rights that correspond to Man by the fact to be a member of society".

Human rights can also be defined, according to Enrique Pérez LA, et al. [14] as "a set of faculties and institutions that, in each historical moment, fulfill the demands of human dignity, freedom and equality, which must be positively recognized by the legal systems national and international levels". It is 
a concept that has in its essence the basis for the emergence of the first ideas related to human rights, since it starts with dignity, individual and personal character, and then relates them to freedom and equality, two presuppositions for the conquest of these rights, in the civil and political dimensions.

Belisário S, et al. [15] recalls that human rights "will be those essential, without which the established concept of life is not recognized. There is no established and final relationship of such rights, since their character is progressive, corresponding at every moment to the cultural stage of civilization, as can be seen from successive 'generations'". In this definition, human rights have a historical bias, in which, in the author's view, their evolution occurred sequentially, as conceived in the theory of dimensions.

Human rights are also the object of an interesting definition presented by Alexandre De M, et al. [3], by which they can be understood as:

The institutionalized set of rights and guarantees of the human being whose basic purpose is to respect their dignity, through their protection against the discretion of state power and the establishment of minimum living conditions and development of human personality can be defined as rights fundamental human beings.

Another definition, elaborated by De Carvalho RA, et al. [6], sums up the essence of what comes to be human rights: "Human rights consist of a set of rights considered indispensable for a human life based on freedom, equality and dignity. Human rights are the essential and indispensable rights to a dignified life".

As we see, almost all definitions of human rights refer to them as a "set of rights". In fact, human rights cannot be reduced to a single right, since all individual, social and transindividual rights are derived from these rights, which presumes their broad character. De Carvalho RA, et al. [6], even, points out that there is no predetermined definitive list of this minimum set of fundamental rights for the dignity of the human person, since each human being, in each time and place, has different needs, varying these rights according to each context, and it is exactly in function of these new demands that these rights are positivized and, in turn, become part of the human rights relationship.

De Carvalho RA, etal. [6] complements this understanding as follows:

Human rights represent essential values, which are explicitly or implicitly portrayed in the Constitutions or in international treaties. The fundamentality of human rights can be formal, through the inclusion of these rights in the list of rights protected in the Constitutions and treaties, or it can be material, being considered an integral part of human rights that which - even if not expressed - is indispensable for the promotion of human dignity [6].

"In general, every right expresses the power to demand from a third party, which may be the State or even a private individual, a certain obligation" [6]. According to the author, in the case of human rights, as they have a varied structure, they can come in four ways [6]:

- Right-Pretension: it is the search for something, with the counterpart of duty (basic premise) of another, such as, for example, the right to basic education, in which the State has the duty to provide it free of charge, under the terms of art. 208, I, CF/88.

- Right-Freedom: which consists of the absence of right (basic premise), that is, the right to act without the interference of the rights of third parties, such as, for example, freedom of belief, according to art. 5th, VI, of $\mathrm{CF} / 88$.

- Right-Power: according to which the individual has the power to demand certain subjection (basic premise) from third parties or the State to comply with a certain rule, as in the case of the provisions of art. 5, LXIII, of $\mathrm{CF} / 88$, which confers the power to demand that, when arrested, the person may request the assistance of a family and a lawyer, in which the public authority is obliged to give this measure.

- Right-Immunity: corresponds to the right that the rule confers on the individual that third parties or the State is incompetent (basic premise) to interfere in their personal sphere. As an example, we can cite the immunity of the person to prison, except in cases of flagrante delicto or by express and reasoned order of the competent judicial authority, or in cases of military transgression or properly military crime, under the terms of art. 5th, LVI, of CF/88.

\section{Human Rights and Fundamental Rights}

There are several ways to designate "human rights", depending on the period covered by the object of study. According to De Carvalho RA, et al. [6], this variety of terminologies is observed both in doctrines and in national and international diplomas, but all of them serve to designate the essential rights of the individual, namely: human rights, human rights, individual rights, fundamental rights, natural rights, public freedoms, subjective public rights, fundamental freedoms. However, they refer to the same thing.

All this diversity of terms is the result of the historical evolution in which human rights took place, as well as from the redesign in which they were delimited and grounded. As these rights were conquered and a document expressed this conquest, there was a heterogeneous use of expressions, but with the same meaning: human rights. 
For example, the 1948 American Declaration of the Rights and Duties of Man adopts the phrases "human rights" and "essential human rights". The Charter of the United Nations uses the expression "human rights" as well as "fundamental freedoms", both with the same meaning. The Universal Declaration of Human Rights, in turn, mentions in its preamble "human rights" and, shortly after, "fundamental human rights", as well as "fundamental human rights and freedoms". The Charter of the United Nations uses the expression "human rights" as well as "fundamental freedoms", both with the same meaning. The 2000 Charter of Fundamental Rights of the European Union uses the term "fundamental rights" and the European Convention on Human Rights and Fundamental Freedoms of 1950 adopted the phrase "fundamental freedom" [6]. Although, in most cases, these terms have the same meaning, it may nevertheless occur that in some contexts they are designating different meanings. However, the most used expressions in the $20^{\text {th }}$ and $21^{\text {st }}$ century are two: human rights and fundamental rights.

From 1948, with the positivization of international norms for the protection of human rights, the so called "global normative system of human rights" was constructed Franklin Seixas AF, et al. [16]. These rules, in order to be valid in the States, must go through a recognition process, which occurs differently in each one, depending on their normative system.

As De Carvalho RA, et al. [6] well teaches, the majority doctrine tends to recognize that "human rights" are used to "define the rights established by international law in treaties and other international norms on the matter, while the expression 'fundamental rights' would delimit those rights recognized and affirmed by the constitutional law of a specific state ". Thus, from this internalization, with the recognition of these human rights norms "they are called 'fundamental rights', based on their fundamentality in the protection of human beings, guaranteeing them the minimum essential that ensures their dignity", as explained by Franklin Seixas $\mathrm{AF}$, et al. [16].

Gomes CJJ, et al. [7], endorsing this distinction, explains that the expressions "human rights" and "fundamental rights" are generally used as synonyms, but that, according to their origin and meaning, we could distinguish them as follows: "Human rights are rights that are valid for all peoples and at all times (jusnaturalist-universalist dimension); fundamental rights are the rights of man, legally and institutionally guaranteed and limited in time and space". For the author, human rights derive from human nature itself, hence its inviolable, timeless and universal character; fundamental rights are those related to those in force in a given legal system.
It is the same conception of Alexandre De M, et al. [3], who, by differentiating human rights from fundamental rights, explains that human rights are inherent to the human condition itself, without any connection with other peculiarities of individuals or groups of these. The author conceptualizes, in turn, that fundamental rights are "human rights recognized as such by the authorities to which the political power to issue norms is attributed, both within States and at the international level; they are the human rights positivized in the Constitutions, in the laws, in the international treaties" [3].

It should also be mentioned here, Filho C, et al. [12], who explains the difference between human rights and fundamental rights well and briefly:

Really, fundamental rights and human rights, these (human) are rights attributed to humanity in general, through international treaties (Universal Declaration of Human Rights, UN, 1948, for example). Fundamental rights, on the other hand, are those positivized in a specific legal system (Brazilian Constitution, German Fundamental Law, etc.).

In our work, we adopted the methodology described by Gomes CJJ, et al. [7] for the designation of "human rights" and "fundamental rights". However, we will approach the expression "fundamental rights" in a more specific way when we deal with these rights related to Brazilian domestic law, starting from the Federal Constitution of 1988 [17].

\section{Human Rights Characteristics}

Human rights, as well as other types of rights, have their own characteristics. These characteristics can be presented according to their nature, ownership and principles. The doctrine has some main characteristics:historicity, universality, essentiality, unavoidability, inalienability, inexhaustibility, imprescriptibility, prohibition of retrogression and effectiveness.

According to, the knowledge and study of these characteristics is important for two reasons: the first is because it allows an understanding of the stage in which the protection of human rights is found in the international order; the second reason, of an internal nature, is that knowledge of these characteristics is important for the operator of the law, since Brazil is a signatory to several international human rights treaties, with binding force under Brazilian law.

In the case of Brazil, human rights standards have a constitutional stature, being higher than the infraconstitutional standards after their approval, as provided for in $\S 3$ of Article 5 of the Federal Constitution of 1988 [7]: "The international treaties and conventions on rights human beings that are approved, in each House of the National 
Congress, in two rounds, by three fifths of the votes of the respective members, will be equivalent to the constitutional amendments". De Carvalho RA, et al. [18] clarifies: "In Brazil, for example, the rules that define individual rights and guarantees are inserted in the Constitution and still considered stony clauses, that is, immutable, as they are not subject to modification even by the action of the Derived Constituent Power". Therefore, given the importance of these characteristics, we will start to see, briefly,

The first characteristic, historicity, is the result of real situations, built over time and according to the conditions of each era. For Ricardo C, et al. [11], historicity is opposed to the naturalist conception (whose rights are timeless and fixed), since it stems from historical evolution, and, in the case of fundamental rights, also vary according to the place in this regard, also states: "human rights, however fundamental they are, are historical rights, that is, born in certain circumstances, characterized by struggles in defense of new freedoms against old powers, and born gradually".

Another characteristic is universality, which corresponds to the aspect of ownership of human rights, as a right that belongs to all people, without distinction. According to André Ramos T, et al. [13], this characteristic tries to attribute the ownership of these rights to all human beings, "regardless of any other additional quality, such as nationality, political choice, sexual orientation, creed, among others".

The fact that human rights are essential in nature represents the characteristic called essentiality. According to De Oliveira MV, et al. [19], they have content "the supreme values of the human being and the prevalenceandof human dignity (countúmaterial), proving to be essential, alsoIt ism, for its special positionherethe normative (countúformal)".

Human rights are considered an intrinsic value of human beings, and they cannot be given up. Having it is not part of a choice, as it is a right that arises from birth, and, as a universal value, it does not only concern its holder. According to Alexandre De M, et al. [3], "fundamental human rights cannot be the object of renunciation", giving this characteristic the name of unenforceability. This characteristic recommends that the authorization for the violation of its content by the holder renouncing that right cannot be justified or validated, as explains: "The non-renunciability conveys the message that people do not have the power to dispose of the protection of their dignity, not having the power to renounce the protection inherent to human dignity". Brings the emblematic example of the French case of throwing dwarfs ". According to him, it was a form of entertainment for bars in France, already in the 1990s, which consisted of throwing (playing) the dwarfs as if they were objects, towards a mattress track, in which the dwarf who would throw the dwarf further away. It turns out that, in the French city of Morsang-sur-Orge, the City Hall vetoed the joke, banning the practice and closing bars that violated the new law.

The case ended up in court, going to the Council of State (the highest body of French justice), which, in turn, dismissed the request to repeal the municipal law. The most curious detail of all history is that the said law was questioned by one of the dwarves, Mr. Manuel Wackenheim. The applicant claimed in his application that that practice was his job, therefore, his only means of subsistence. In other words, it did not matter to the dwarf whether that practice was also an unworthy form of human treatment, because for him, the most important thing was his survival. The legal discussion ended up at the UN Human Rights Council, which agreed with the French court's decision, also understanding that that practice violated the dignity of the human person. Therefore,

Other situations can serve as examples of this same characteristic, such as those involving suicide, euthanasia, abortion, among others. In any case, what can be seen is that dignity is such an important value that no human being has the right to give it up. In addition to being inalienable, human rights are also inalienable, which gives rise to another characteristic, inalienability,and it means that human rights are not subject to negotiation, of any kind, whether onerous or free. Filho C, et al. explains: "To sell means to transfer ownership. As a rule, fundamental rights cannot be sold, donated, lent, etc.". For the author, human rights are rights of objective effectiveness, as they are of interest to the entire community. However, there are some exceptions, such as the right to property, which even though it is a fundamental right, can be alienated (we emphasize that not the right itself, but the property as an object).

Human rightsarealso inexhaustible, that is, inexhaustible, in the sense that they will always be possible to expand, adding at any time new rights to those that already exist, just as we have observed the evolution of rights throughout history. This corresponds to the other characteristic of human rights, inexhaustibility. In Brazil, we can find an example of this inexhaustibility in the constitutional text, as provided for in $\S 2$ of Article 5 of the 1988 Constitution: "The rights and guarantees expressed in this Constitution do not exclude others arising from the regime and principles adopted by it, or from the international treaties to which the Federative Republic of Brazil is a party" De Oliveira MV, et al. [19], in this regard,they can be complemented both by rights arising from the regime and the principles adopted by it and by rights arising from international (human rights) treaties to which Brazil is a party".

In the list of characteristics, wealso find imprescriptibility, which means that human rights are not achieved by the end 
of the term, that is, they do not cease to exist over time. According to: "Imprescriptibility means that the claim of respect and realization of human rights does not end over the years, and can be demanded at any time". This characteristic, it is worth mentioning, does not refer to the prescription related to the repair of damages for violations of human rights, but only to the claim of respect for these rights.

Since human rights are the result of a historical evolution, it is not possible for him to suffer setbacks, starting to protect fewer rights than he protects, which is the essence of the characteristic known as sealing the setback. For this reason, it is forbidden for States to back down on matters related to human rights, or fundamental rights. Likewise, international treaties can only have rules that expand the list of existing rights, being prevented from reducing or eliminating rights. De Oliveira MV, et al. [19] explains: "if a later rule revokes or nullifies a more beneficial previous rule, that later rule is invalid because it violates the international principle of the prohibition of backsliding (also known as the 'return ban' principle, 'no return' or 'click effect"'.

Regarding the characteristics of human rights [3], discusses in his doctrine about effectiveness, which is related to the performance of the Public Power, responsible for guaranteeing and enforcing the rights provided for in the legal system of each country, using, if necessary, its coercive power so that these rights are respected.

Finally, it is necessary to mention indivisibility, also called unity or interdependence, a characteristic that "it means that human rights must be understood as a set, as a single, indivisible and interdependent block of rights". In this regard, De Carvalho RA, et al. [6] explains that all human rights must be recognized in a homogeneous and unified manner, without privileging one right in relation to others, since everyone must have the same legal protection, an essential condition to provide a dignified life to all. In turn, Filho C, et al. [12] observes that the disrespect to any of these rights, consequently, will be a disrespect to the whole set of human rights: "theto make an exception in relation to one is to do so in relation to all. You can't disrespect fundamental rights 'just a little bit', or 'just for one person' ".

\section{Conclusion}

This work aims to present and discuss the contemporary conception of human rights theory. In it, a theoretical approach was carried out on the main concepts and definitions, foundations, characteristics and distinctions about these rights.

Human rights are inherent to all human beings, regardless of race, sex, nationality, ethnicity, language, religion or any other condition. They are basic rights, such as the right to life, to equality, among many others, and have as a principle the dignity of the human person [20]. In this sense, we can affirm that human rights are one of the main achievements of humanity in the contemporary era, however, we must understand that this achievement is due to historical struggles and that go back centuries.

A detailed study of human rights is important so that its concepts are better understood and applied. Understanding the theoretical framework in the light of contemporary conceptions gives more solidity to reflection on such a vast and globally relevant topic. Any incomplete or incorrect understanding consequently compromises the entire understanding of the legal system, both nationally and internationally, as well as any notion of justice $[20,21]$.

However, it is necessary that human rights receive permanent attention, because, as society evolves and becomes more complex, new rights also appear, creating the need for a new approach and reflection regarding these rights. In addition, the idea of human rights are principles that must be defended worldwide, as it concerns everyone, including future generations.

Therefore, this theme deserves a permanent and indepth study, with new approaches and discoveries, mainly because it is a topic of relevance to society and every new idea has a great contribution for everyone.

\section{References}

1. United Nations Organization (2020) What are human rights?. UN Information Center for Brazil. Rio de Janeiro: UNIC.

2. Melina Girardi F (2015) Human Rights and Development. Rio de Janeiro: Renew.

3. Alexandre De M (1998) Fundamental human rights: general theory, comments on arts. $1^{\text {st }}$ to $5^{\text {th }}$ of the Constitution of the Federative Republic of Brazil, doctrine and jurisprudence. São Paulo: Atlas.

4. Sven P (2009) Practical handbook on international human rights, Brasília-DF: Superior School of the Federal Public Ministry (ESMPU).

5. Rafael B (2019) Human rights. $9^{\text {th }}$ (Edn.), rev and ampl. Salvador: JusPodivm.

6. De Carvalho RA (2018) Human rights course. $5^{\text {th }}$ (Edn.), São Paulo: Saraiva Educação.

7. Gomes CJJ (1993) Constitutional right. $6^{\text {th }}$ (Edn.), rev. 
Coimbra: Livraria Almedina.

8. Norberto B (2004) The era of rights. Translation: Carlos Nelson Coutinho. Rio de Janeiro: Elsevier.

9. De Souza NG (2016) Human rights versus public security. Rio de Janeiro: Forensics.

10. Walter K, Jorg K (2013) Universeller menschenrechtsschutz: der schutz des individuums auf globaler und regionaler erbene (Universal protection of human rights: protecting individuals at the global and regional levels). Germany: Nomos Verlagsgesellschaft.

11. Ricardo C (2019) Human rights. 6th (Edn.), São Paulo: Saraiva Educação.

12. Filho C, Trindade J (2010) General theory of fundamental rights.

13. André Ramos T (2018) Constitutional law course. $16^{\text {th }}$ (Edn.), rev and current. São Paulo: Saraiva.

14. Enrique Pérez LA (1979) Conceptual Delimitation of Human Derechos. In: Humanos LD, et al. (Eds.), Significación, Legal Statute and System. Sevilla: Publications de la Universidad de Sevilla.
15. Belisário S (1996) Human Rights Prioritized by Justice. Magazine of the Faculty of Law of Faculdades Metropolitanas Unidas.

16. Franklin Seixas AF, Mello VG (2018) Human rights. Porto Alegre: SAGAH.

17. (1988) Constitution of the Federative Republic of Brazil: constitutional text promulgated, compiled up to Constitutional Amendment no108/2020. Brasília: Federal Senate, Coordination of Technical Editions, 2021.

18. De Carvalho RA (2016) General theory of human rights in the international order. $6^{\text {th }}$ (Edn.), São Paulo: Saraiva.

19. De Oliveira MV (2018) Human rights course. 5th (Edn.), Rev. current. and ampl. Rio de Janeiro: Forensic; São Paulo.

20. United Nations Organization (1948) Universal Declaration of Human Rights. United Nations Brazil. Rio de Janeiro: UNIC.

21. Flávia P (2006) Constitutional Law Booklet. School of the Judiciary of the Federal Regional Court of the $4^{\text {th }}$ Region. 